\title{
ANTIBACTERIAL AND ANTIBIOFILM SCREENING OF NEW PLATINUM(IV) COMPLEXES WITH SOME S-ALKYL DERIVATIVES OF THIOSALICYLIC ACID"
}

\author{
Ivana Radojevići ${ }^{*}$, Sava Vasić1 ${ }^{1}$ Ljiljana Čomić ${ }^{1}$, Srećko Trifunović ${ }^{1}$, \\ Marina Mijajlović², Miloš Nikolić2 ${ }^{2}$ Gordana Radić ${ }^{2}$ \\ ${ }^{1}$ University of Kragujevac, Faculty of Science, Department of Biology and Ecology, \\ Radoja Domanovića 12, PO Box 60, 34000 Kragujevac, Republic of Serbia \\ ${ }^{2}$ University of Kragujevac, Medical Sciences, Svetozara Markovića 69, 34000 Kragujevac, \\ Republic of Serbia \\ *Corresponding author; E-mail: ivana@kg.ac.rs
}

(Received March 10, 2017; Accepted May 1, 2017)

\begin{abstract}
The influence of 5 new Platinum(IV) (Pt(IV)) complexes with S-alkyl derivatives of thiosalicylic acid (C1-benzyl, C2-methyl, C3-ethyl, C4-propyl and C5butyl) was studied on 16 strains of bacteria. Antibacterial activity was tested using microdilution method with resazurin while antibiofilm activity was observed by tissue culture plate method, using doxycycline as a positive control. The results were expressed as minimum inhibitory concentration (MIC), minimum bactericidal concentration (MBC) and biofilm inhibitory concentration (BIC). The best result on Gram positive bacteria exhibited C1 and MIC was $<7.81 \mu \mathrm{g} / \mathrm{ml}$ against Staphylococcus aureus ATCC 25923. Bifidobacterium animalis subsp. lactis (probiotic) was sensitive to C2 (MIC at 15.625 $\mu \mathrm{g} / \mathrm{ml}$ ). The highest sensitivity of Gram negative bacteria was observed in Escherichia coli ATCC 25922 treated with C1, C2, C3 and C4, in Proteus mirabilis ATCC 12453 treated with C1, and in Pseudomonas aeruginosa treated with C2, C3 and C5 (all MICs at $250 \mu \mathrm{g} / \mathrm{ml}$ ). The $\mathrm{C} 2$ complex were more efficient as antibiofilm agents and the best results were obtained with $\mathrm{C} 2$ acting against $S$. aureus and S. aureus ATCC 25923 biofilms. In conclusion, we noticed that the tested compounds exhibited promising properties as antibacterial and antibiofilm agents.
\end{abstract}

Key words: platinum(IV) complex, antibacterial activity, antibiofilm.

\section{INTRODUCTION}

The interest in determining the influence of new metal complexes on microorganisms is increasing due to the growing resistance of pathogenic bacteria. Studies on antimicrobial activity of platinum ( $\mathrm{Pt}(\mathrm{IV})$ ) complexes have been conducted, showing wide influence on microorganisms but being more or less effective.

\footnotetext{
\# A large part of this manuscript was presented at the Second International Electronic Conference on Medicinal Chemistry (ECMC-2); November 2016; www.sciforum.net/conference/ecmc-12.
} 
Staphylococcus aureus, as Gram positive bacteria and Shigella flexneri, as Gram negative were a part of AL-HASANI (2007) investigation of the antibacterial activity for the ligand and their metal complexes, which were bimetallic. Square planar Pd (II) and octahedral Pt (IV) complexes with novel spherical aramides nanoparticles containing flexible linkages ligands were tested for antimicrobial activity (ELHUSSEINY and HASSAN, 2013). In this investigation, Pt complexes as polymeric nanoparticles showed high potency as antitumor and antimicrobial agents. Different polymers with Pt(IV) (NARTOP et al., 2013) exhibited a moderate activity against selected microorganisms. Pt(IV) complexes with unsymmetrical tetradentate schiff bases (HEGAZY and GAAFAR, 2012) have been tested on Bacillus subtilis, $S$. aureus, Escherichia coli, Salmonella typhi, also yeast and fungi. They have proven to act as antimicrobials. Other studies of platinum (Pt(IV)) complexes include Pt(IV) chelate (HEGAZY, 2012), Pt(IV) dithiocarbamate complexes (MANAV et al., 2006), thiodiamines with Pt(IV) (MISHRA and KAUSHIK, 2007), etc.

The goal of this study was in vitro testing of new synthesized $\mathrm{Pt}(\mathrm{IV})$ complexes (labeled as: $\mathrm{C} 1$ for $\mathrm{Pt}\left(\mathrm{S}\right.$-bz-thiosal) ${ }_{3}, \mathrm{C} 2$ for $\mathrm{Pt}\left(\mathrm{S}\right.$-met-thiosal) ${ }_{3}, \mathrm{C} 3$ for $\mathrm{Pt}(\mathrm{S}$-et-thiosal) 3 , C4 for $\mathrm{Pt}(\mathrm{S} \text {-pr-thiosal })_{3}$ and $\mathrm{C} 5$ for $\left.\mathrm{Pt}(\mathrm{S} \text {-bu-thiosal })_{3}\right)$ in order to obtain information on their antimicrobial activity and for the first time the antibiofilm activity of any of $\mathrm{Pt}(\mathrm{IV})$ complexes.

\section{MATERIALS AND METHODS}

\section{Chemicals}

Ammonium sulphate was purchased from Zorka Pharma (Šabac, Serbia), magnesium sulphate from Merck-Alkaloid (Skopje, FYRM), while potassium dihydrogen phosphate and sodium dihydrogen citrate were purchased from Kemika (Zagreb, Croatia). Dimethyl sulfoxide (DMSO) was purchased from Acros Organics (New Jersey, USA). Resazurin was obtained from Alfa Aesar GmbH \& Co. (KG, Karlsruhe, Germany). Crystal violet stain was obtained from Fluka AG (Buchs SG, Switzerland), nutrient liquid medium, a Mueller-Hinton broth was purchased from Torlak (Belgrade, Serbia), an antibiotic, doxycycline, from Galenika A.D. (Belgrade, Serbia).

\section{The synthesis of complexes}

The platinum(IV) complexes with an S-alkyl derivatives of thiosalicylic acid $\left[\mathrm{PtCl}_{2}\right.$ (S-R-thiosal $)_{2}$ ] were obtained by reacting potassium heksahloridoplatinata (IV) and S-alkyl derivatives of thiosalicylic acid ( $\mathrm{R}=$ benzyl, methyl-, ethyl-, propyl- or butyl) in a molar ratio of 1:2 with the addition of aqueous lithium hydroxide (Scheme 1). S-alkyl derivatives of thiosalicylic acid were synthesized according to the procedure described by SMITH et al., (2011).

S-alkyl derivatives of thiosalicylic acid (for C1-benzyl, C2-methyl, C3-ethyl, C4propyl and C5-butyl) in amount of $0.6 \mathrm{mmol}$ was slowly added to the solution of $0.2 \mathrm{mmol}$ $(0.1 \mathrm{~g})$ potassium-hexachloroplatinum(IV) with $10 \mathrm{ml}$ of distilled water. The reaction mixture was heated in a water bath with stirring for $3 \mathrm{~h}$. During this period, small portions from a solution of $\mathrm{LiOH}(0.6 \mathrm{mmol}$ with $10 \mathrm{ml}$ of distilled water) were added. The precipitate of the complex was separated by filtration, rinsed with distilled water and dried in air. 


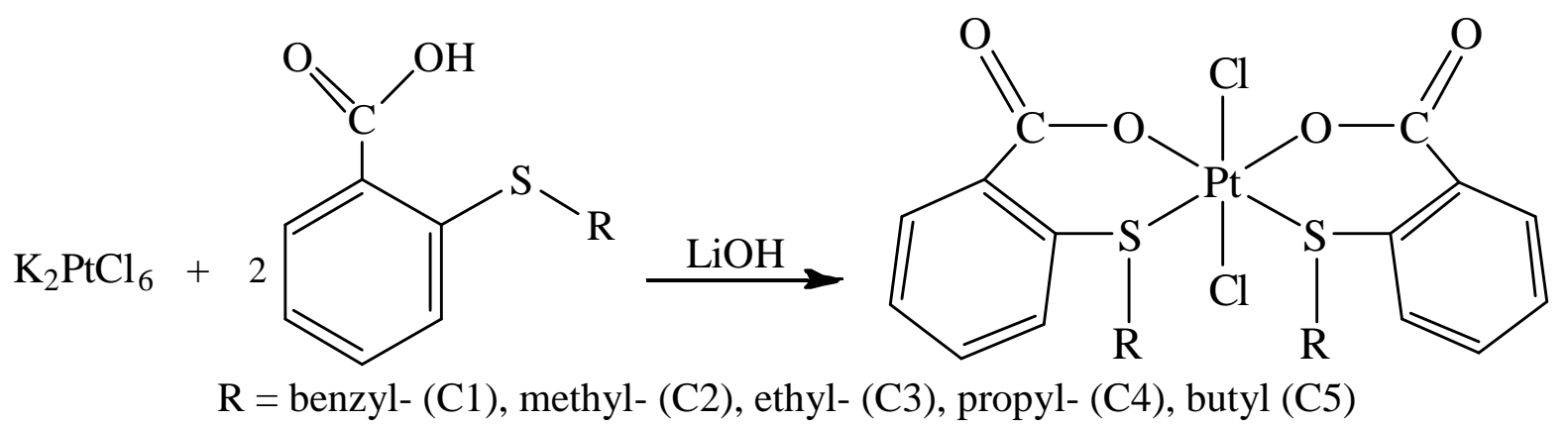

Scheme 1. Synthesis of the platinum complexes (IV) with S-alkyl derivatives of thiosalicylic acid.

\section{Determination of antibacterial and antibiofilm activity}

\section{Test microorganisms}

The antibacterial activity was tested against 16 strains of bacteria (Table 1) and antibiofilm activity against 4 bacterial strains (Table 2). All clinical isolates were a generous gift from the Institute of Public Health, Kragujevac, Serbia. The ATCC strains were provided from a collection held by the Microbiology Laboratory, Faculty of Science, University of Kragujevac.

\section{Suspension preparation}

The suspensions were prepared by direct colony method. The turbidity of the initial suspension was adjusted using 0.5 McFarland densitometer (DEN-1, BioSan, Latvia). The initial suspensions were additionally diluted in 1:100 ratio in sterile $0.85 \%$ saline.

\section{Microdilution method}

Antibacterial activity was tested by determining the minimum inhibitory concentration (MIC) and the minimum bactericidal concentration (MBC) using microdilution method with resazurin (SARKER et al., 2007). The tested compounds were first dissolved in dimethyl sulfoxide (DMSO) (10\% of total volume) and then into nutrient liquid medium (up to $100 \%$ of total volume). The stock concentrations of tested compounds were $2000 \mu \mathrm{g} / \mathrm{ml}$. Next, serial twofold dilutions were made in a concentration range from $1000 \mu \mathrm{g} / \mathrm{ml}$ to $7.81 \mu \mathrm{g} / \mathrm{ml}$ in sterile 96-well microtiter plates containing nutrient broth. After that, $10 \mu \mathrm{l}$ of diluted suspensions were added to appropriate wells. Finally, $10 \mu \mathrm{l}$ resazurin solution, as an indicator of microbial growth, was added to each well. Resazurin is a blue non-fluorescent dye that becomes pink and fluorescent when reduced to resorufin by oxidoreductases within viable cells. The inoculated plates were incubated at $37^{\circ} \mathrm{C}$ for $24 \mathrm{~h}$. MIC was defined as the lowest concentration of tested substance that prevented resazurin color change from blue to pink. Minimum bactericidal concentration was determined by plating $10 \mu 1$ of samples from wells, where no indicator color change was recorded, on nutrient agar medium. At the end of the incubation period the lowest concentration with no growth (no colony) was defined as minimum bactericidal concentration (MBC).

Doxycycline, dissolved in nutrient liquid medium, was used as a positive control. Solvent control test was performed to study an effect of $10 \%$ DMSO on the growth of microorganisms. Each test included growth control and sterility control. All tests were performed in duplicate and MICs were constant. 


\section{Tissue culture plate method (TCP)}

The TCP assay described by CHRISTENSEN et al. (1985) is the most widely used test for detection of biofilm formation. We screened all strains for their ability to form biofilm by TCP method with some modifications. Each test included biofilm formation control. Bacterial biofilm formation properties were well described by O'ToOLE et al. (2000).

The tissue culture 96-well plates (Sarstedt AG \& Co., Germany) were prepared by dispensing $100 \mu \mathrm{l}$ of nutrient broth, Mueller-Hinton broth for bacteria, into each well. A $10 \mu \mathrm{l}$ of fresh bacterial suspension was added to each well. The inoculated plates were incubated at $37^{\circ} \mathrm{C}$ for $24 \mathrm{~h}$ for Gram negative bacteria and $48 \mathrm{~h}$ for Gram positive bacteria. A $100 \mu \mathrm{l}$ from the stock solution of tested complexes (concentration of $2000 \mu \mathrm{g} / \mathrm{ml}$ ) was added into the first row of the plate. Then, twofold, serial dilutions were made for each next row using a multichannel pipette. After $24 \mathrm{~h}$, the incubation content of each well was gently removed by tapping the plates. The wells were washed with $200 \mu \mathrm{l}$ of saline buffer $(0.15 \mathrm{M}$ ammonium sulfate, $0.1 \mathrm{M}$ potassium dihydrogen phosphate, $0.034 \mathrm{M}$ sodium dihydrogen citrate and $0.001 \mathrm{M}$ magnesium sulphate) to remove free-floating bacteria. Biofilms formed by adherent cells in plate were stained with crystal violet $(0.1 \% \mathrm{w} / \mathrm{v})$ and incubated at the room temperature for 20 minutes. Excess stain was rinsed off by thorough washing with deionized water and plates were fixed with $200 \mu \mathrm{l}$ of ethanol-acetone solution (4:1). Optical densities (OD) of stained adherent bacteria were determined with a micro ELISA plate reader at wavelength of $630 \mathrm{~nm}(\mathrm{OD} 630 \mathrm{~nm})$. Biofilm inhibitory concentration (BIC) was defined as the lowest concentration of each complex where the biofilms were dispersed. Only broth or broth with dissolved complexes served as control to check sterility and non-specific binding of the media. All tests were performed in duplicate.

\section{RESULTS AND DISCUSSION}

\section{Antibacterial activity}

The test results of in vitro antibacterial activity of $\mathrm{Pt}(\mathrm{IV})$ complexes are presented in Table 1. The detected values were in range from less than 7.81 up to more than $1000 \mu \mathrm{g} / \mathrm{ml}$. For comparison, MIC and MBC values of doxycycline are also listed. Gram positive bacteria showed higher sensitivity than Gram negative bacteria.

Significant sensitivity of Gram positive bacteria in the presence of $\mathrm{Pt}(\mathrm{IV})$ complexes, was observed in Bifidobacterium animalis subsp. lactis, B. subtilis, S. aureus and S. aureus ATCC 25923. The best result was obtained with C1 with MIC on S. aureus ATCC 25923 was $<7.81 \mu \mathrm{g} / \mathrm{ml}$. B. animalis subsp. lactis (probiotic) showed high sensitivity in relation to $\mathrm{C} 1$ (MIC at $62.5 \mu \mathrm{g} / \mathrm{ml}$ ) and even higher sensitivity in relation to C2 (MIC at $15.625 \mu \mathrm{g} / \mathrm{ml}$ ). MIC for the Gram-negative bacteria was in the range from 250 to $>1000 \mu \mathrm{g} / \mathrm{ml}$. The highest sensitivity was observed in E. coli ATCC 25922 in relation to C1, C2, C3 and C4, Proteus mirabilis ATCC 12453 in relation to $\mathrm{C} 1$ and Pseudomonas aeruginosa in relation to $\mathrm{C} 2, \mathrm{C} 3$ and C5 (all MICs at $250 \mu \mathrm{g} / \mathrm{ml}$ ).

Comparing the results obtained for the Pt(IV) complexes with the results of corresponding ligands from which they were synthetized (RADIĆ et al., 2012) it can be concluded that these complexes had better antibacterial activity than the ligands. HEGAZY and GAAFAR (2012) tested synthetized Pt(IV) complex on 10 pathogenic bacteria and had high efficiency against all the strains, including Salmonella sp., S. aureus and B. subtilis, while the $\mathrm{Pt}(\mathrm{IV})$ dithiocarbamate complexes investigated by MANAV et al. (2006) were less active against E. coli, B. subtilis and $P$. aeruginosa. 
Table 1. Antibacterial activity of Pt(IV) complexes C1 to C5 and positive control (doxycycline), MIC values ( $\mu \mathrm{g} / \mathrm{ml})$ - mean inhibitory activity, MBC values $(\mu \mathrm{g} / \mathrm{ml})$ - mean bactericidal activity.

\begin{tabular}{lcccccccccccc}
\hline & \multicolumn{3}{c}{ C1 } & \multicolumn{2}{c}{ C2 } & \multicolumn{2}{c}{ C3 } & \multicolumn{2}{c}{ C4 } & \multicolumn{2}{c}{ C5 } & Doxycycline \\
\cline { 2 - 11 } Species & MIC & MBC & MIC & MBC & MIC & MBC & MIC & MBC & MIC & MBC & MIC & MBC \\
\hline Lactobacillus plantarum & 500 & 1000 & 500 & 1000 & 500 & 1000 & 500 & 1000 & 500 & 1000 & 0.45 & 7.81 \\
Bifidobacterium animalis subsp. lactis & 62.5 & 125 & 125 & 250 & 125 & 250 & 250 & 250 & 250 & 250 & 31.25 & 62.5 \\
Bacillus subtilis IP 5832 & 500 & 500 & 500 & $>1000$ & 1000 & 1000 & 1000 & 1000 & 1000 & 1000 & 1.95 & 15.63 \\
B. subtilis & 62.5 & 500 & 250 & 500 & 31.25 & 500 & 62.5 & 500 & 62.5 & 500 & 0.11 & 1.95 \\
B. subtilis ATCC 6633 & 1000 & 1000 & 1000 & 1000 & 1000 & 1000 & 1000 & $>1000$ & 1000 & $>1000$ & 1.95 & 31.25 \\
Staphylococcus aureus & 62.5 & 125 & 62.5 & 500 & 250 & 500 & 250 & 500 & 250 & 500 & 0.45 & 7.81 \\
S. aureus ATCC 25923 & $<7.81$ & 62.5 & 125 & 250 & 125 & 500 & 125 & 250 & 125 & 250 & 0.22 & 3.75 \\
Enterococcus faecalis & 1000 & 1000 & 500 & 500 & 100 & 1000 & 1000 & 1000 & 1000 & 1000 & 7.81 & 62.5 \\
Escherichia coli & 1000 & 1000 & 500 & 500 & 500 & 1000 & 500 & 1000 & 500 & 1000 & 7.81 & 15.63 \\
E. coli ATCC 25922 & 250 & 500 & 250 & 500 & 250 & 500 & 250 & 500 & 250 & 500 & 15.63 & 31.25 \\
Proteus mirabilis & 1000 & 1000 & 1000 & 1000 & 1000 & 1000 & 1000 & 1000 & 1000 & 1000 & 250 & 500 \\
P. mirabilis ATCC 12453 & 250 & 500 & 500 & 500 & 500 & 500 & 1000 & 1000 & 1000 & 1000 & 15.63 & 62.5 \\
Pseudomonas aeruginosa & 500 & $>1000$ & 250 & 1000 & 250 & 1000 & 500 & $>1000$ & 500 & $>1000$ & 250 & 1000 \\
P. aeruginosa ATCC 27853 & 1000 & 1000 & 1000 & 1000 & 1000 & $>1000$ & 1000 & $>1000$ & 1000 & $>1000$ & 62.5 & 125 \\
Salmonella enterica & 1000 & 1000 & 500 & 500 & 500 & 1000 & 500 & 1000 & 500 & 1000 & 15.63 & 31.25 \\
Salmonella typhimurium & 1000 & 1000 & 500 & 500 & 500 & 1000 & 500 & 1000 & 500 & 1000 & 15.63 & 125 \\
\hline
\end{tabular}




\section{Antibiofilm activity}

Biofilm appears when microbial cells get attached to the surface and get embedded in the extracellular polymeric substances (EPS) (DONLAN, 2002). Biofilms are making various problems in food industry, medicine and everyday life. Antibiofilm examinations are a step forward in preclinical testing in microbiology. Bacteria which are in biofilm structure are different than planktonic cells and are generally more resistant to antimicrobial agents (LEWIS, 2001), so we decided to perform the test on 4 strains of bacteria to obtain the in vitro antibiofilm activity of $\mathrm{Pt}(\mathrm{IV})$ complexes. The results are presented in Table 2 . The best results were obtained with C2 acting against $S$. aureus and $S$. aureus ATCC 25923 biofilm and it was noticed that obtained values were lower than antibiotic values which is important to notice because this is the first antibiofilm testing of this kind of complexes.

Table 2. Antibiofilm activity of Pt(IV) complexes C1 to C5 and positive control (doxycycline), BIC values $(\mu \mathrm{g} / \mathrm{ml})$ - biofilm inhibitory concentration, $\mathrm{nt}-$ not tested.

\begin{tabular}{lcccccc}
\hline \multirow{2}{*}{ Species } & C1 & C2 & C3 & C4 & C5 & Doxycycline \\
\cline { 2 - 7 } & \multicolumn{7}{c}{ BIC } \\
\hline Staphylococcus aureus & 250 & 62.5 & 125 & 500 & 125 & 250 \\
\hline S. aureus ATCC 25923 & 500 & 62.5 & 1000 & 250 & 1000 & 250 \\
\hline Proteus mirabilis ATCC 12453 & 1000 & $>1000$ & 1000 & $\mathrm{nt}$ & 1000 & $\mathrm{nt}$ \\
\hline Pseudomonas aeruginosa & 1000 & 1000 & 1000 & 1000 & 1000 & 2000 \\
\hline
\end{tabular}

\section{CONCLUSIONS}

The Pt(IV) complexes showed a significant activity against the tested bacteria. The strongest antibacterial and antibiofilm activity was observed against $S$. aureus and $S$. aureus ATCC 25923. Since these bacteria can cause different medical problems, the potential use of $\mathrm{Pt}(\mathrm{IV})$ complexes should be the subject of future studies.

\section{Acknowledgments}

This work was supported by the Ministry of Education, Science and Technological Development of the Republic of Serbia.

\section{References:}

[1] Al-Hasani, A.M.R. (2007): Preparation, structural and antimicrobial studies of a new bimetallic complexes involving a new schiff and mannich bases. Journal of Al-Nahrain University 10: 39-49.

[2] Christensen, G.D., Simpson, W.A., Younger, J.J., Baddour, L.M., Barrett, F.F., MELTON, D.M., BEACHEY, E.H. (1985): Adherence of coagulase-negative Staphylococci 
to plastic tissue culture plates: a quantitative model for the adherence of Staphylococci to medical devices. Journal of Clinical Microbiolog. 22: 996-1006.

[3] DONLAN, R.M. (2002): Biofilms: microbial life on surfaces. Emerging Infectious Diseases 8: 881-890.

[4] Elhusseiny, A.F., HAssan, H.H.A.M. (2013): Antimicrobial and antitumor activity of platinum and palladium complexes of novel spherical aramides nanoparticles containing flexibilizing linkages: Structure-property relationship. Spectrochimica Acta Part A: Molecular and Biomolecular Spectroscopy 103: 232-245.

[5] Hegazy, W.H. (2012): Synthesis of organometallic-based biologically active compounds: In vitro antibacterial and antifungal of asymmetric ferrocene-derived schiff-bases chelates. International Research Journal of Pure and Applied Chemistry 2: 170-182.

[6] Hegazy, W.H., GAAfAR, M. (2012): Synthesis, characterization and antibacterial activities of new Pd (II) and Pt (IV) complexes of some unsymmetrical tetradentate schiff bases. American Chemical Science Journal 2: 86-99.

[7] LEWIS, K. (2001): Riddle of biofilm resistance. Antimicrobial Agents and Chemotherapy 45: 999-1007.

[8] ManAv, N., Mishra, A.K., KAUSHIK, N.K. (2006): In vitro antitumour and antibacterial studies of some Pt (IV) dithiocarbamate complexes. Spectrochimica Acta Part A: Molecular and Biomolecular Spectroscopy 65: 32-35.

[9] Mishra, A.K., KAUSHIK, N.K. (2007): Synthesis, characterization, cytotoxicity, antibacterial and antifungal evaluation of some new platinum (IV) and palladium (II) complexes of thiodiamines. European Journal of Medicinal Chemistry 42: 1239-1246.

[10] NARTOP, D., SARI, N., ÖGÜTÇÜ, H. (2013): Pt(IV) complexes with polystrene-bound schiff bases as antimicrobial agent: Synthesis and characterization. Proceedings of World Academy of Science, Engineering and Technology. World Academy of Science, Engineering and Technology (WASET) No: 78.

[11] O'Toole, G., Kaplan, H.B., Kolter, R. (2000): Biofilm formation as microbial development. Annual Review of Microbiology 54: 49-79.

[12] Radić, G., GloĐović, V., Radojević, I., Stefanović, O., Čomić, LJ., Ratković, Z., VALKONEN, A., RisSANEN, K., TRIFUnOVIĆ, S. (2012): Synthesis, characterization and antimicrobial activity of palladium(II) complexes with some alkyl derivates of thiosalicylic acids. Crystal structure of bis(S-benzyl-thiosalicylate)-palladium(II) complex, [Pd(S-bz-thiosal)2]. Polyhedron 31: 69-76.

[13] SARKer, S.D., NAHAR, L., Kumarasamy, Y. (2007): Microtitre plate-based antibacterial assay incorporating resazurin as an indicator of cell growth, and its application in the in vitro antibacterial screening of phytochemicals. Methods 42: 321-324.

[14] Smith, D.J., YaP, G.P., Kelley, J.A., SchneIder, J.P. (2011): Enhanced stereoselectivity of a $\mathrm{Cu}$ (II) complex chiral auxiliary in the synthesis of Fmoc-L- $\gamma$-carboxyglutamic acid. The Journal of Organic Chemistry 76: 1513-1520. 